\title{
Weed Management Practices for Organic Production of Trailing Blackberry, II. Accumulation and Loss of Biomass and Nutrients
}

\author{
Renee H. Harkins ${ }^{1}$ and Bernadine C. Strik ${ }^{2,3}$ \\ Department of Horticulture, Oregon State University, 4017 ALS, Corvallis, \\ OR 97331 \\ David R. Bryla \\ U.S. Department of Agriculture, Agricultural Research Service, Horticultural \\ Crop Research Unit, 3420 NW Orchard Avenue, Corvallis, OR 97330
}

Additional index words. landscape fabric, organic fertilizer, Rubus, tissue nutrient status weed control

\begin{abstract}
A study was conducted in western Oregon to assess the impact of cultivar and weed management strategy on accumulation and loss of plant biomass and nutrients during the first 3 years of establishment when using organic fertilizer. The study was conducted in trailing blackberry (Rubus L. subgenus Rubus Watson) planted in May 2010 and certified organic in May 2012. Treatments included two cultivars, Marion and Black Diamond, each with either no weed control after the first year after planting or with weeds managed by hand-weeding or the use of weed mat. Each treatment was amended with organically approved fertilizers at pre-plant and was drip-fertigated with fish emulsion each spring. Most primocane leaf nutrient concentrations were within the range recommended for blackberry. However, leaf nitrogen $(\mathrm{N})$ was low in 'Black Diamond', especially when grown without weed control, whereas leaf boron (B) was low in all treatments. In many cases, leaf nutrient concentrations were affected by cultivar and weed management in both the primocanes and the floricanes. The concentration of several nutrients in the fruit differed between cultivars, including calcium (Ca), magnesium (Mg), sulfur (S), B, and zinc ( $\mathrm{Zn})$, but only fruit $\mathrm{Ca}$ was affected by weed management and only in 'Marion'. In this case, fruit Ca was higher when the cultivar was grown with weed mat than with hand-weeding or no weeding. Total biomass production of primocanes increased from an average of $0.3 \mathrm{t} \cdot \mathrm{ha}^{-1}$ dry weight (DW) during the first year after planting to $2.0 \mathrm{t} \cdot \mathrm{ha}^{-1} \mathrm{DW}$ the next year. Plants were first cropped the third year after planting and gained an additional $3.3 \mathrm{t} \cdot \mathrm{ha}^{-1} \mathrm{DW}$ in total aboveground biomass (primocanes, floricanes, and fruit) by the end of the third season. Fruit DW averaged 1.4 t.ha ${ }^{-1}$ in non-weeded plots, $1.9 \mathrm{t} \cdot \mathrm{ha}^{-1}$ in hand-weeded plots, and $2.3 \mathrm{t} \cdot \mathrm{ha}^{-1}$ in weed mat plots. Biomass of senesced floricanes (removed after harvest) averaged $3.2 \mathrm{t} \cdot \mathrm{ha}^{-1} \mathrm{DW}$ and was similar between cultivars and among the weed management treatments. 'Marion' primocanes accumulated a higher content of $\mathrm{N}$, phosphorus $(\mathrm{P})$, potassium $(\mathrm{K}), \mathrm{Mg}, \mathrm{S}$, iron $(\mathrm{Fe}), \mathrm{B}$, copper $(\mathrm{Cu})$, and aluminum (Al) than in 'Black Diamond'. Weeds, however, reduced nutrient accumulation in the primocanes in both cultivars, and accumulation of nutrients was greater in the floricanes than in the previous year's primocanes. Total nutrient content declined from June to August in the floricanes, primarily through fruit removal at harvest and senescence of the floricanes after harvest. Depending on the cultivar and weed management strategy, nutrient loss from the fruit and floricanes averaged 34 to $79 \mathrm{~kg} \cdot \mathrm{ha}^{-1}$ of N, 5 to $12 \mathrm{~kg} \cdot \mathrm{ha}^{-1}$ of $\mathrm{P}, 36$ to $84 \mathrm{~kg} \cdot \mathrm{ha}^{-1}$ of $\mathrm{K}, 23$ to $61 \mathrm{~kg} \cdot \mathrm{ha}^{-1}$ of Ca, 5 to $15 \mathrm{~kg} \cdot \mathrm{ha}^{-1}$ of $\mathrm{Mg}, 2$ to $5 \mathrm{~kg} \cdot \mathrm{ha}^{-1}$ of $\mathrm{S}, 380$ to $810 \mathrm{~g} \cdot \mathrm{ha}^{-1}$ of Fe, 70 to $300 \mathrm{~g} \cdot \mathrm{ha}^{-1}$ of $\mathrm{B}, 15$ to $36 \mathrm{~g} \cdot \mathrm{ha}^{-1}$ of $\mathrm{Cu}, 610$ to $1350 \mathrm{~g} \cdot \mathrm{ha}^{-1}$ of manganese (Mn), 10 to $260 \mathrm{~g} \cdot \mathrm{ha}^{-1} \mathrm{of} \mathrm{Zn}$, and 410 to $950 \mathrm{~g} \cdot \mathrm{ha}^{-1}$ of Al. Overall, plants generally accumulated (and lost) the most biomass and nutrients with weed mat and the least with no weed control.
\end{abstract}

Received for publication 9 Sept. 2013. Accepted for publication 7 Nov. 2013.

We thank Gil Buller and Emily Vollmer for technical assistance and acknowledge financial support from NIFA-OREI (2010-01940; ORE00409), the Northwest Center for Small Fruits Research, and our industry contributors.

${ }^{1}$ Graduate Student.

${ }^{2}$ Professor.

${ }^{3}$ To whom reprint requests should be addressed; e-mailstrikb@hort.oregonstate.edu.
Recent surveys show a shift toward more organic blackberry production worldwide (Strik et al., 2007). Approximately 200 ha of organic blackberry are currently planted in the United States, $74 \%$ of which are located in California and Oregon (National Agricultural Statistical Service, 2010). Some of the challenges to increased organic blackberry production include costly fertilization practices and limited options for control of weeds, insects, and plant diseases. Management practices that minimize fertilizer inputs and sustain good plant growth and yield without use of chemicals not certified as organic are therefore needed for continued expansion of organic production of blackberries. The common weed management methods used in organic blackberry fields include handweeding, use of woven landscape fabric (often referred to as "weed cloth" or "weed mat"), and no or limited weeding. In the latter case, weeds are typically removed during the first few months after planting to help establish the plants and then only mowed or removed just before fruit harvest.

Trailing blackberry is a perennial crop, but like other caneberry species, the shoots or canes of the plant are biennial. Vegetative canes, referred to as primocanes, emerge from the plant crown each spring and become floricanes with flowers and fruit the next spring. Mature plants will have both primocanes and floricanes in the same year in a typical annual or every-year production system and during the "on-year" of an alternateyear production system (Julian et al., 2009; Strik and Finn, 2012). Fruit ripen in the summer and are usually machine-harvested for processing. Primocanes rely primarily on soil nutrients and fertilizers for growth, whereas floricanes rely largely on plant nutrient reserves (Malik et al., 1991; Mohadjer et al., 2001). Partitioning and accumulation of nutrients is a function of sink strength, and most nutrients accumulate in the floricanes in the spring and in the primocanes (and below ground in the crown and roots) in the summer and fall (Cortell and Strik, 1997; Mohadjer et al., 2001). Fertilizer applications are split; half is applied in early spring, primarily for growth of primocanes and development of fruiting laterals and fruit, and the other half is applied in late spring or early summer for continued primocane growth (Hart et al., 2006). Some growers, however, including those producing organic blackberries, fertigate with liquid fertilizers and inject the fertilizer through the drip irrigation system (Kafkafi and Tarchitzky, 2011). In this case, fertilizer is typically applied more frequently from early spring to midsummer.

Nitrogen is the primary nutrient applied to blackberry in Oregon, although P, K, and B are sometimes applied as well. In conventional plantings, Hart et al. (2006) recommend 35 to $55 \mathrm{~kg} \cdot \mathrm{ha}^{-1}$ of $\mathrm{N}$ during the first year or two of establishment and 55 to 80 $\mathrm{kg} \cdot \mathrm{ha}^{-1}$ of $\mathrm{N}$ once the planting matures. They also recommend as much as $90 \mathrm{~kg} \cdot \mathrm{ha}^{-1}$ of $\mathrm{P}$ $\left(\mathrm{P}_{2} \mathrm{O}_{5}\right), 45$ to $110 \mathrm{~kg} \cdot \mathrm{ha}^{-1}$ of $\mathrm{K}\left(\mathrm{K}_{2} \mathrm{O}\right)$, and 1 to $3 \mathrm{~kg} \cdot \mathrm{ha}^{-1}$ of $\mathrm{B}$ based on soil and leaf tissue tests. Organic fertilizers are also applied at similar rates of $\mathrm{N}$, although most are comprised of many nutrients, and therefore other nutrients are added inadvertently. Two of the most common sources of organic fertilizers used in blackberry include dry poultry litter and liquid fish products. Information on the effects of using these organic fertilizers on nutrient balance and plant nutrition is limited in most crops, including blackberry. 
The objective of the present study was to assess the impact of cultivar and weed management strategies on the accumulation and loss of plant biomass and nutrients during the first 3 years of establishment when using organic fertilizers. The study included three methods of weed management (hand-weeding, weed mat, and no weeding) and two cultivars (Marion and Black Diamond) commonly used for processing in Oregon. Previously, we found that weeds reduced yield during the establishment years in both cultivars by $40 \%$ relative to hand-weeding, whereas weed mat increased yield by $20 \%$ relative to handweeding (Harkins et al., 2013). We hypothesized that the treatment effects on yield were attributable, at least in part, to differences in plant nutrition, whereby weeds reduced availability of soil nutrients as a result of competition with the blackberry plants, whereas weed mat, which was black in color, resulted in warmer soil temperatures and increased availability of soil nutrients (Julian et al., 2012; Larco et al., 2013; Makus, 2011; Percival et al., 1998; Strik et al., 2006; Willard and Valenti, 2008), possibly a result of increased mineralization rates and root distribution and development, for example.

\section{Materials and Methods}

Study site. The study was conducted at the Oregon State University, North Willamette Research and Extension Center in Aurora, OR [lat. $45^{\circ} 17^{\prime} \mathrm{N}$, long. $122^{\circ} 45^{\prime} \mathrm{W}$; U.S. Dept. of Agriculture Plant Hardiness Zone 8 (2012); elevation $46 \mathrm{~m}$ ]. Soil at the site is a Willamette silt loam (fine-silty, mixed, superactive mesic Pachic Ultic Argixeroll) that had a $\mathrm{pH}$ of 5.3 before planting and contained $3.6 \%$ organic matter, $1.5 \mathrm{ppm} \mathrm{NO}_{3}-\mathrm{N}, 2.3$ ppm $\mathrm{NH}_{4}-\mathrm{N}, 188$ ppm P (Bray I), and 295 ppm $\mathrm{K}$. Soil $\mathrm{pH}$ and $\mathrm{K}$ were low and below the ranges recommended for the crop (i.e., $\mathrm{pH} 5.6$ to 6.5 and soil $\mathrm{K}$ greater than $350 \mathrm{ppm}$; Hart et al., 2006) and therefore, based on McLean (1982), lime [calcium carbonate $\left(2242 \mathrm{~kg} \cdot \mathrm{ha}^{-1}\right)$ and dolomite (4148 $\left.\mathrm{kg} \cdot \mathrm{ha}^{-1}\right)$ ] and K-Mag fertilizer $\left(102 \mathrm{~kg} \cdot \mathrm{ha}^{-1} \mathrm{~K}, 62 \mathrm{~kg} \cdot \mathrm{ha}^{-1} \mathrm{Mg}\right.$, $\left.102 \mathrm{~kg} \cdot \mathrm{ha}^{-1} \mathrm{~S}\right)+$ micronutrients $\left[2 \mathrm{~kg} \cdot \mathrm{ha}^{-1} \mathrm{~B}\right.$ $\left(\mathrm{H}_{3} \mathrm{BO}_{3}\right), 1 \mathrm{~kg} \cdot \mathrm{ha}^{-1} \mathrm{Cu}\left(\mathrm{CuSO}_{4}\right)$, and 14 $\left.\mathrm{kg} \cdot \mathrm{ha}^{-1} \mathrm{Zn}\left(\mathrm{ZnSO}_{4}\right)\right]$ were broadcast and incorporated into each row before planting. The field was planted with tissue-cultured plugs on 26 May 2010 and certified organic by Oregon Tilth (Salem, OR) in May 2012. See Harkins et al. (2013) for further information on site preparation, irrigation, and weather conditions.

Experimental design. Treatments were arranged as a split-split-split plot design with five replicates and included a row of 'Marion' and a row of 'Black Diamond' as main plots, two irrigation strategies (postharvest and no postharvest irrigation) as subplots, and a combination of three weed management strategies (weed mat, hand-weeding, and no weeding) and two primocane training dates (August and February) as sub-subplots. Each sub-subplot consisted of four plants spaced $1.5 \mathrm{~m}$ apart inrow and was separated from plants in adjacent plots by $3.0 \mathrm{~m}$ (to provide space for clearing the machine harvester). Between-row spacing was $3.0 \mathrm{~m}$ (2222 plants/ha). Four border plants at the end of each row and border rows surrounded the planting. Overall, there were 12 rows that were $104 \mathrm{~m}$ long $(0.4 \mathrm{ha})$ and a total of 120 treatment plots. Because irrigation and training treatments could not be initiated until after the first year of fruit production in Year 3 (Aug. 2012), any samples collected from these treatments were pooled in the present study.

Primocane training. Annual development of the planting is illustrated in Fig. 1. Plants were trained on a two-wire vertical trellis system in each row that was installed before planting. The lower trellis wire was attached to steel posts at $1.0 \mathrm{~m}$ above the ground, and the upper wire was attached at $1.6 \mathrm{~m}$. Primocanes were tied to the trellis as they grew during first 2 years after planting, using twine, but were cut to the crown and removed in February after the first season to increase growth the next year, the standard commercial practice. Once the primocanes grew above the upper trellis wire in the second year, half the canes were looped in one direction down to the lower trellis wire and brought back toward the plant with one or two twists and the other half was looped in the opposite direction. By Year 3, plants had primocanes and floricanes (the previous year's primocanes). At this point, new primocanes were left on the ground alongside the row and, depending on the training date treatment, were tied to the trellis in August or February.

Fertilizer applications. Plants were irrigated by drip and fertilized using pelletized, processed poultry litter $(4 \mathrm{~N}-3 \mathrm{P}-2 \mathrm{~K}-7 \mathrm{Ca}$; Nutri-Rich; Stutzman Environmental Products Inc., Canby, OR) and Fish Agra (4N$1 \mathrm{P}-1 \mathrm{~K}$; Northeast Organics, Manchester-bythe-Sea, MA) in 2010 and TRUE 402 liquid fertilizer $(4 \mathrm{~N}-0 \mathrm{P}-2 \mathrm{~K}$; True Organic Products, Inc., Spreckels, CA) in 2011 and 2012. The Nutri-Rich was incorporated into the soil $\left(\approx 0.45 \mathrm{~m}\right.$ diameter) at a rate of $28 \mathrm{~kg} \cdot \mathrm{ha}^{-1} \mathrm{~N}$ just before planting. Fish Agra was diluted with 10 parts water (v/v) and applied by hand, around the base of plants, in seven weekly applications of $4 \mathrm{~kg} \cdot \mathrm{ha}^{-1} \mathrm{~N}$ each from 14 July to 25 Aug. 2010 ( $28 \mathrm{~kg} \cdot \mathrm{ha}^{-1}$ total N). TRUE 402 was also diluted with 10 parts water but applied by fertigation (injection through the drip system) using a Mix-Rite TF10-002 fertilizer injector (DEMA, St. Louis, MO). Irrigation was run for $10 \mathrm{~min}$ before each injection to fully pressurize the system and was run for an additional hour afterward to flush the drip lines. Plants were fertigated with fish emulsion to provide $8.0 \mathrm{~kg} \cdot \mathrm{ha}^{-1} \mathrm{~N}$ on $15 \mathrm{Apr}$. and $16 \mathrm{~kg} \cdot \mathrm{ha}^{-1} \mathrm{~N}$ each on 9 May and 1 and 20 June in 2011 and with $14 \mathrm{~kg} \cdot \mathrm{ha}^{-1}$ $\mathrm{N}$ each on 23 Apr., 8 May, and 7 and 13 June in $2012\left(56 \mathrm{~kg} \cdot \mathrm{ha}^{-1}\right.$ total $\mathrm{N}$ per year). The fertilizers applied were analyzed for total nutrient content (Brookside Laboratories, New Bremen, $\mathrm{OH}$ ), and the rate of all macroand micronutrients applied was calculated (Table 1).

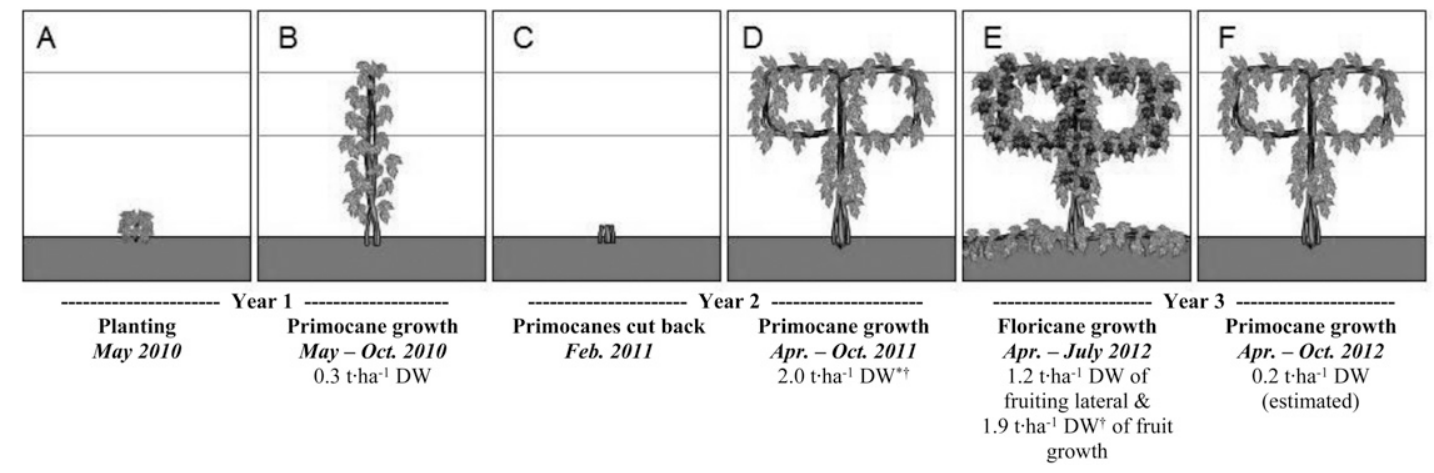

Fig. 1. A new planting of organic trailing blackberry, 2010-12: (A) tissue-cultured plug plants at planting, May 2010; (B) primocane growth in 2010; (C) primocanes cut back to crown, Feb. 2011; (D) primocane growth in 2011; (E) floricane growth in 2012 (with new primocanes left on the ground); and (F) new primocanes trained to a trellis (after senesced floricanes were removed), Aug. 2012. Cultivars in the planting included 'Black Diamond' and 'Marion', and weed management strategies included hand-weeding or weed mat in Year 1 and no weeding, hand-weeding, and weed mat in Years 2 and 3. Plant dry weight (DW) data were adapted from Harkins et al. (2013). Plant DW was measured in Feb. 2011 (Year 1), Jan. 2012 (Year 2), and July 2012 (floricanes and fruit in Year 3); each measurement includes the average of two cultivars ('Black Diamond' and 'Marion') and three weed management strategies (no weeding, handweeding, and weed mat); an asterisk after DW indicates a significant difference between cultivars $(P<0.05)$ and a dagger indicates a significant difference among the weed management strategies $(P<0.01)$. All interactions between cultivar and weed management on DW were nonsignificant. 
Table 1. Total nutrients in organic fertilizers applied to trailing blackberry plants during the first three growing seasons (2010-12).

\begin{tabular}{|c|c|c|c|c|c|c|c|c|c|c|}
\hline \multirow[b]{2}{*}{ Fertilizer $^{z}$} & \multicolumn{6}{|c|}{ Macronutrients $\left(\mathrm{kg} \cdot \mathrm{ha}^{-1}\right)$} & \multicolumn{4}{|c|}{ Micronutrients $\left(\mathrm{g} \cdot \mathrm{ha}^{-1}\right)$} \\
\hline & $\mathrm{N}$ & $\mathrm{P}$ & $\mathrm{K}$ & $\mathrm{Ca}$ & $\mathrm{Mg}$ & $\mathrm{Na}$ & B & $\mathrm{Cu}$ & $\mathrm{Mn}$ & $\mathrm{Zn}$ \\
\hline 2010 & & & & & & & & & & \\
\hline Nutra-Rich & 26 & 16 & 18 & 80 & 5 & 3 & 24 & 38 & 314 & 274 \\
\hline Fish-Agra & 28 & 7 & 7 & 6 & 1 & N/A & 2 & 38 & 4 & 20 \\
\hline 2011 and 2012 & & & & & & & & & & \\
\hline TRUE 402 & 53 & 7 & 62 & 1 & 1 & 26 & 11 & 6 & 18 & 79 \\
\hline
\end{tabular}

${ }^{2}$ Nutra-Rich and TRUE 402 were analyzed by Brookside Laboratories, Inc. (New Bremen, OH). Values for Fish-Agra were obtained from the product label. Nutra-Rich was a pelletized poultry liter product incorporated in the soil along the row just before planting. The product had a $\mathrm{pH}$ of 8.3. Fish-Agra and True 402 were hydrolyzed fish products mixed 1:10 (v/v) with water before application. Nutra-Rich had a pH of 7.3 and TRUE 402 had a pH of 5.5. Fish-Agra was applied by hand around the base of the plants in seven equal applications of $\approx 4 \mathrm{~kg} \cdot \mathrm{ha}^{-1}$ nitrogen $(\mathrm{N})$ each. TRUE 402 was applied by fertigation through the drip system and was injected in four equal applications of $\approx 14 \mathrm{~kg} \cdot \mathrm{ha}^{-1} \mathrm{~N}$ each per year.

$\mathrm{N} / \mathrm{A}=$ not available.

Weed management. Weeds were removed with a hoe from hand-weeded plots and from the planting hole, by hand, of weed mat plots. Weeds were also hand-hoed from non-weeded plots during the first year after planting in 2010 to encourage growth and establishment of the treatment, but left unchecked until harvest the next years, when weeds were mowed to the ground in the plots with a string trimmer in late June to avoid any interference with the machine harvester and avoid potential contamination of the fruit with weed seeds (standard commercial practice). See Harkins et al. (2013) for further information on weed management treatments and weed production in each treatment.

Measurements. Primocane DW was measured after the first and second years after planting in Feb. 2011 and Jan. 2012. One primocane was randomly selected from two plants per plot each year and oven-dried at $70{ }^{\circ} \mathrm{C}$ to a constant weight to determine the average individual DW of the primocanes in each treatment. Primocane individual DW was then multiplied by the total number of primocanes counted in each plot and divided by plot area to calculate total primocane DW per hectare. Total primocane DW was also estimated after the third season by counting the number of primocanes in each plot in Jan. 2013 and using the linear relationship between primocane number and DW from the previous season to calculate total DW [primocane DW $=-6.5^{*}(\text { primocane number })^{2}+$ $178.2 *$ (primocane number) $-305.6 ; r^{2}=$ $0.53 ; P<0.0001]$.

Ripe fruit were harvested twice weekly from 5 July to 30 July 2012 using an over-therow rotary harvester (Littau Harvesters Inc., Stayton, OR). Total marketable fruit was weighed on each harvest date from each treatment plot. At midharvest on 16 July, a 60 -g subsample of ripe fruit was collected from each plot and shipped overnight to Brookside Laboratories to determine percent water content and calculate the total DW of the fruit in each treatment. Fruit water content averaged $87 \%$ in 'Black Diamond' and $84 \%$ in 'Marion' and was $2 \%$ higher in both cultivars with either method of weed control than with no weeding (Harkins et al., 2013).

Floricane DW (canes and fruiting laterals) was measured in early August immediately after the final harvest date in 2012. A floricane was randomly selected from two plants per plot and oven-dried at $70{ }^{\circ} \mathrm{C}$ and weighed to determine total floricane DW per hectare based on floricane counts as was done with the primocanes. The floricanes were then cut to the crown, placed between rows, and flailmowed (standard commercial practice). Once floricanes were removed, new primocanes produced in the summer-trained plots were trained to the trellis wire, whereas those in the winter-trained plots were left on the ground until February.

Leaf samples were collected from the primocanes on 18 Aug. 2011 and 31 July 2012 per standard recommendations (Hart 2012 (first black fruit stage), oven-dried, ground, and analyzed for nutrients on each date at Brookside Laboratories. Ten recent fully expanded leaves were collected from each plot on each sample date. Total $\mathrm{N}$ content was determined in each sample using a combustion analyzer, and $\mathrm{P}, \mathrm{K}, \mathrm{Ca}, \mathrm{Mg}, \mathrm{S}, \mathrm{Fe}, \mathrm{B}$, $\mathrm{Cu}, \mathrm{Mn}, \mathrm{Zn}$, and $\mathrm{Al}$ were determined using an inductively coupled plasma spectrophotometer after wet-ashing the samples in nitric/ perchloric acid (Gavlak et al., 1994). The primocanes, fruit, and floricanes harvested for DW were also ground and analyzed for nutrient concentration and used to calculate total aboveground plant nutrient content per hectare each year. See Harkins (2013) for a complete summary of primocane and floricane nutrient concentrations in each treatment.

Data analysis. The experimental design was a split-split-split plot as described previously; however, because irrigation and training treatments were not initiated during these establishment years, these sub-subplot treatments were pooled and data analyzed as a split-plot design with cultivars (two levels) as the main plot and weed management treatment (three levels) as the subplot effects. Years were analyzed separately because the planting was maturing with only primocanes present in Years 1 and 2 and floricanes and primocanes in Year 3. Data were analyzed using PROC GLM in SAS (SAS Institute Inc., Cary, NC). Significant main effects of weed management were separated at the $5 \%$ level using Fisher's protected least significant difference test. When interactions beet al., 2006) and from the floricanes on 3 July tween cultivar and weed management were significant $(P \leq 0.05)$, Student's $t$ test was used to determine differences between cultivars within each weed management treatment and Tukey's honestly significant difference test was used to separate means within each cultivar.

\section{Results and Discussion}

Leaf and fruit nutrient concentrations. Most primocane and floricane leaf nutrient concentrations differed between cultivars and, in many cases, were affected by the method of weed management (Table 2). In general, 'Marion' had higher concentrations of macronutrients in the primocane leaves than 'Black Diamond'-in both the second summer after planting when the plants had no fruit and the third summer after planting when the plants were cropped - but had a lower concentration of all but $\mathrm{K}$ in the floricane leaves. 'Black Diamond', on the other hand, had similar or higher concentrations of most micronutrients, except $\mathrm{Zn}$ in the primocane leaves and $\mathrm{B}$ in the floricane leaves. In the latter case, a significant interaction between cultivar and weed management revealed that floricane leaf B was only higher in 'Marion' than in 'Black Diamond' when plants were grown in non-weeded plots (Fig. 2).

Leaf nutrient concentrations were often higher with weed control than without it, including $\mathrm{N}, \mathrm{P}, \mathrm{K}, \mathrm{S}, \mathrm{Cu}$, and $\mathrm{Zn}$ in the primocane leaves during the second year after planting and $\mathrm{N}$ (weed mat only) and $\mathrm{S}$ in the primocane leaves and N, P, Ca (handweeding only), $\mathrm{Mg}$ (hand-weeding only), $\mathrm{S}$, and $\mathrm{Cu}$ in the floricane leaves during the third year (Table 2). Some nutrient concentrations were also higher with weed mat than with hand-weeding such as $\mathrm{P}, \mathrm{S}, \mathrm{Cu}$, and $\mathrm{Zn}$ in the primocane leaves during the second year and $\mathrm{S}$ in the primocane leaves during the third year, whereas others such as $\mathrm{Fe}$ and $\mathrm{Al}$ in the primocane leaves and $\mathrm{P}$ in the floricane leaves were higher the third year with handweeding than with weed mat. Significant interactions between cultivar and weed management indicated that primocane leaf $\mathrm{Fe}$ and floricane leaf $\mathrm{P}$ were only higher with handweeding in 'Black Diamond' with no effect of weed management in 'Marion' (Fig. 3A-B). Likewise, leaf $\mathrm{S}$ in the floricanes was higher with weed control than without it, but only in 'Black Diamond' (Fig. 3C). The only nutrient concentration that was significantly higher with no weeding than with either method of weed control was leaf $\mathrm{Mn}$ in the primocanes - and only during the second year (Table 2). Treatment effects on soil nutrient content and $\mathrm{pH}$ were also measured during the study but were inconsistent and unrelated to plant nutrient content (Harkins, 2013).

Currently, nutrient recommendations for conventional blackberry are based on tissue testing of primocane leaves collected in late July to early August (Hart et al., 2006). As already mentioned, the primary nutrients of 


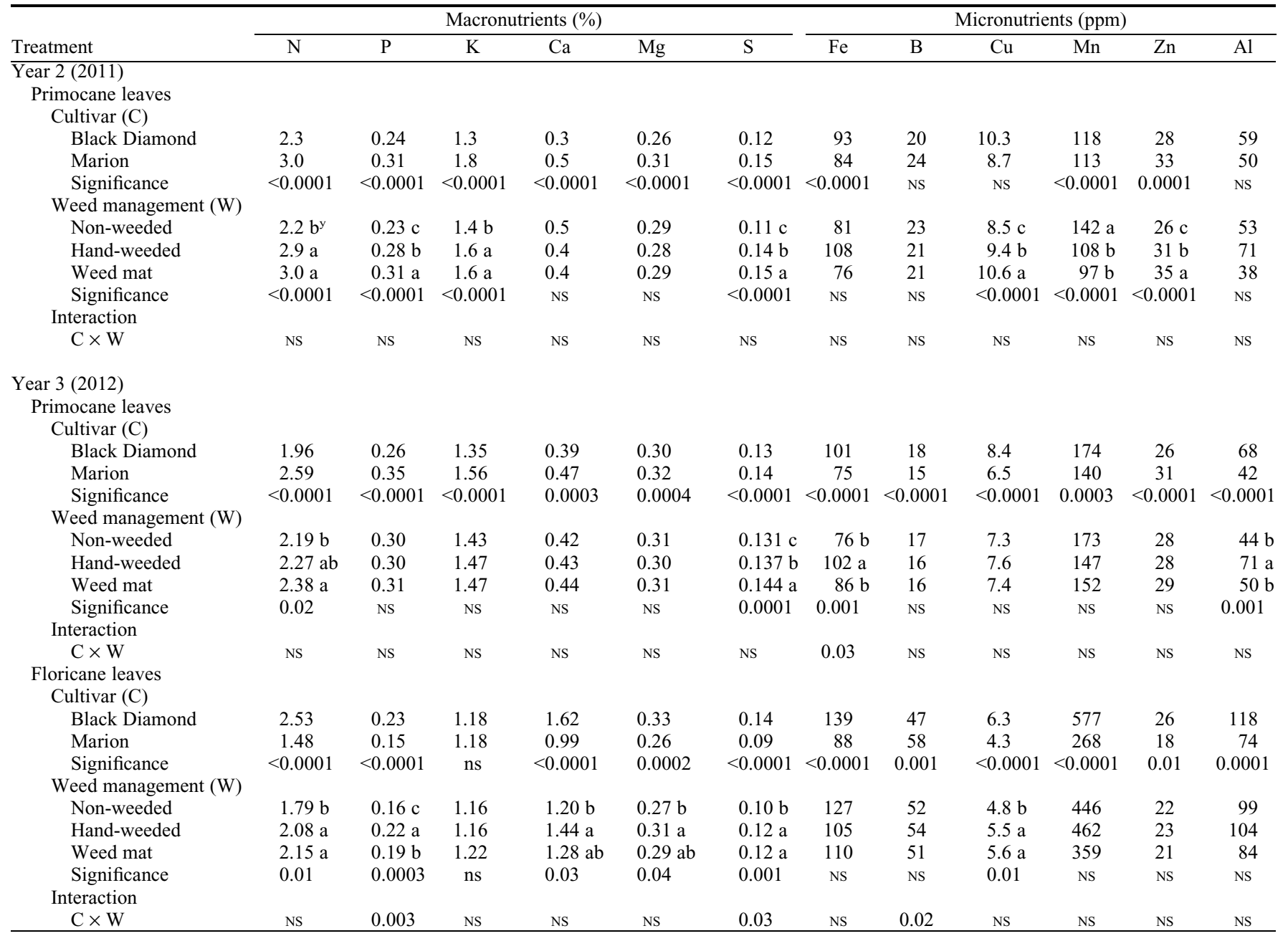

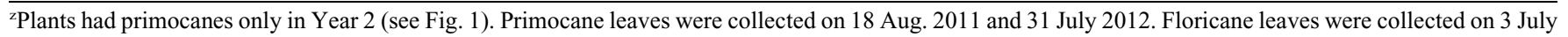
2012 at 1 week before fruit harvest.

${ }^{\mathrm{y}}$ Means were separated at the 0.05 level using Fisher's protected least significant difference test.

NS = nonsignificant.
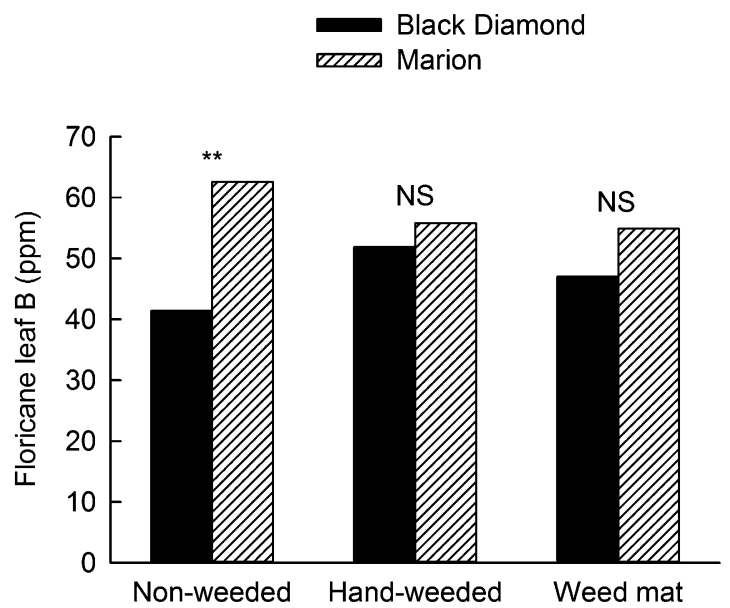

Fig. 2. Effects of three different weed management strategies on leaf boron (B) concentration in the floricanes during the first year of fruit production (Year 3) in 'Black Diamond' and 'Marion' blackberry. Each bar represents the mean of three replicates. Cultivars were compared within each weed management strategy using the $t$ test. Ns, ${ }^{* *}$ Nonsignificant or significant at $P \leq 0.01$, respectively.

concern in the northwestern United States are $\mathrm{N}, \mathrm{P}, \mathrm{K}$, and $\mathrm{B}$. In the plants grown organically in the present study, primocane leaf $\mathrm{P}$ and $\mathrm{K}$ were well above the recommended levels of $0.19 \%$ and $1.25 \%$, respectively, during the second and third years of the study
(Table 2). Primocane leaf $\mathrm{N}$ was also within the recommended range of $2.3 \%$ to $3.0 \%$, regardless of weed management strategy in 'Marion' each year, but was below the range in 'Black Diamond' grown in non-weeded plots during the second year after planting and all plots during the third year. 'Black Diamond' may therefore either require more $\mathrm{N}$ (fish emulsion) fertilizer than 'Marion', particularly when grown with limited or no weed control, or 'Black Diamond' may have lower $\mathrm{N}$ requirements. Current nutrient recommendations are based primarily on work done in 'Marion', but optimum levels likely vary among cultivars. Total marketable yield was in fact higher in 'Black Diamond' than in 'Marion', suggesting that $\mathrm{N}$ availability was not limiting to early production in the cultivar (Harkins et al., 2013). Low N levels may begin to reduce yield in 'Black Diamond' as the planting matures, and the cultivar may require more $\mathrm{N}$ fertilizer than 'Marion' to maintain adequate plant tissue levels. Better timing of fertilizer application may also improve $\mathrm{N}$ uptake, but information on the optimum time to apply organic fertilizers, 

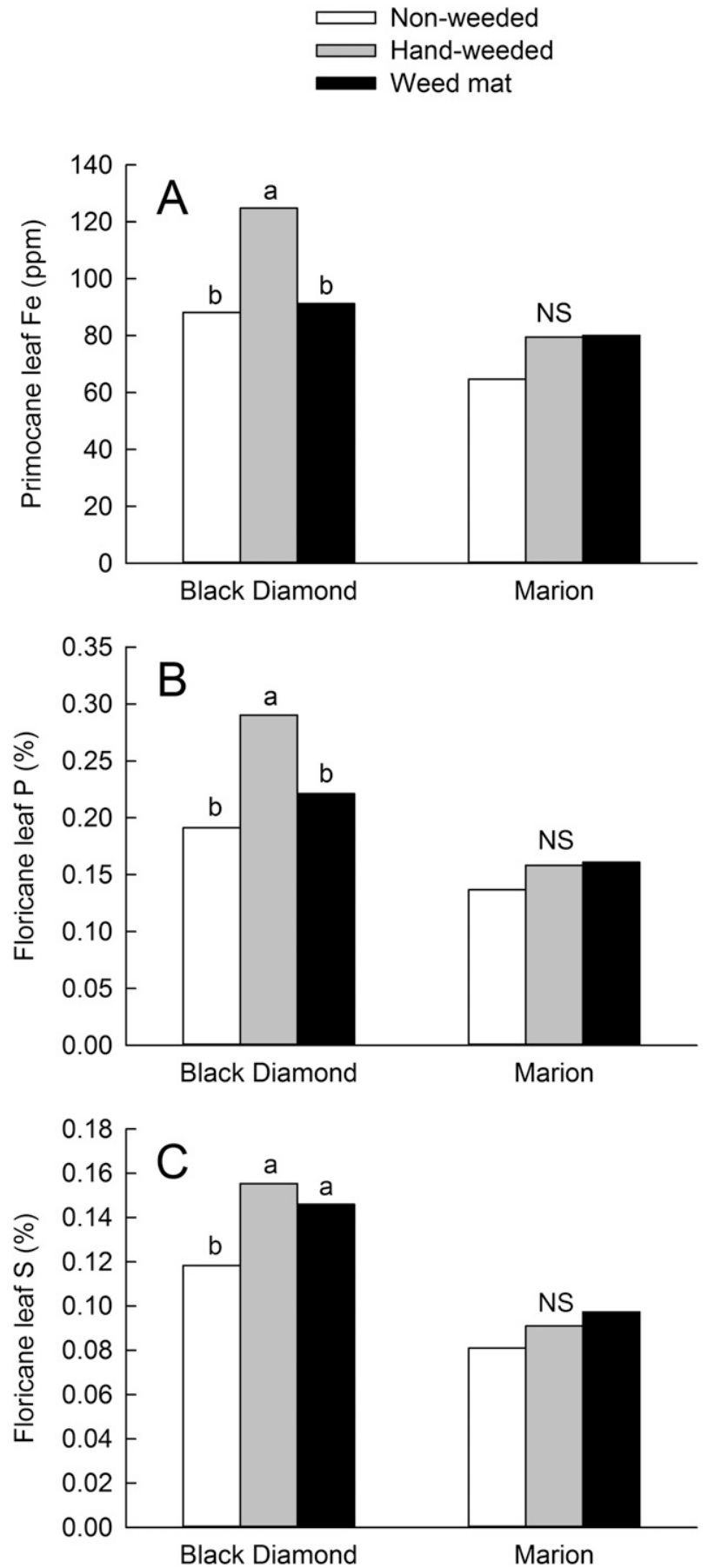

Fig. 3. Effects of three different weed management strategies on $(\mathbf{A})$ leaf iron $(\mathrm{Fe})$ concentration in the primocanes and $(\mathbf{B})$ leaf phosphorus $(\mathrm{P})$, and $(\mathbf{C})$ sulfur $(\mathrm{S})$ concentration in the floricanes during the first year of fruit production (Year 3) in 'Black Diamond' and 'Marion' blackberry. Each bar represents the mean of three replicates. Means were separated within cultivars using Tukey's honestly significant difference test $(P=0.05)$. NS Nonsignificant.

particularly to perennial crops, is limited (Mattson and van Iersel, 2011).

Primocane leaf $\mathrm{B}$ was also below the recommended level of $30 \mathrm{ppm}$ (Hart et al., 2006), but in this case, it was low in both cultivars each year and in all weed management treatments (Table 2). Soil B was also below recommended levels for blackberry at the site (Harkins, 2013; Hart et al., 2006). Boron deficiency is common in the region and may result in reduced yield, small fruit, and, in severe instances, cane dieback. Fortunately, boric acid is an Organic Materials Research Institute-approved source of B fertilizer that is easily applied to blackberry and can be used in organic plantings with $B$ deficiency. Weed mat may be permeable enough to allow for granular fertilizer application to the top of the mulch (Zibilske, 2010).

Fruit nutrient concentrations differed less between cultivars than leaf nutrients and were little affected by the method of weed management (Table 3). In this case, 'Marion' had higher concentrations of $\mathrm{Ca}, \mathrm{Mg}$, and $\mathrm{Zn}$ in the ripe fruit than 'Black Diamond' but had lower concentrations of S and B. Only fruit $\mathrm{Ca}$ concentration was affected by weed control and only in 'Marion' where levels were higher with weed mat than with handweeding or no weeding (Fig. 4). Calcium is primarily transported into plants and plant parts through the transpiration stream (Hanger, 1979; McLaughlin and Wimmer, 1999). Although fruit are low-transpiring organs relative to leaves, fruit transpiration accounts for a large percentage of the total $\mathrm{Ca}$ that enters the fruit (Ho and White, 2005; Montanaro et al., 2006, 2010). Although we did not measure fruit transpiration specifically in our study, we did find that weed mat increased water use in 'Marion', but not in 'Black Diamond', and therefore may have led to higher fruit $\mathrm{Ca}$ levels in the cultivar (Harkins et al., 2013). Currently, the impact of fruit nutrient concentration on fruit quality, particularly fruit $\mathrm{Ca}$ level and associated firmness, is unknown in blackberry.

Accumulation and loss of plant biomass and nutrients. Plant growth was similar regardless of cultivar or method of weed management during the first year after planting, and by the end of the season, primocane tissue DW in each treatment averaged 0.3 t.ha ${ }^{-1}$ (Fig. 1A-B). Because the plants were still small at this point, the primocanes were cut to the ground and removed in February (Fig. 1C) to prevent fruiting the next season and to encourage more primocane growth (Fig. 1D), the standard commercial practice. Nutrient levels measured in the primocanes just before cutting indicated that more $\mathrm{Ca}$, $\mathrm{Mn}, \mathrm{Zn}$, and $\mathrm{Al}$ were removed in 'Black Diamond' than in 'Marion', and more $\mathrm{Fe}, \mathrm{Cu}$, and $\mathrm{Al}$ were removed in hand-weeded plots than in those with weed mat (Table 4). Total removal of other nutrients was similar among treatments and averaged $5.5 \mathrm{~kg} \cdot \mathrm{ha}^{-1}$ of N, 0.5 $\mathrm{kg} \cdot \mathrm{ha}^{-1}$ of P, $2.0 \mathrm{~kg} \cdot \mathrm{ha}^{-1}$ of $\mathrm{K}, 0.5 \mathrm{~kg} \cdot \mathrm{ha}^{-1}$ of $\mathrm{Mg}, 0.3 \mathrm{~kg} \cdot \mathrm{ha}^{-1}$ of S, and $7 \mathrm{~g} \cdot \mathrm{ha}^{-1}$ of B.

Dry weight production of primocanes was four to eight times higher among treatments the second year after planting than the previous year (Fig. 1D). By the end of the second season, total primocane DW averaged 1.8 $\mathrm{t} \cdot \mathrm{ha}^{-1}$ in 'Black Diamond' and $2.2 \mathrm{t} \cdot \mathrm{ha}^{-1}$ in 'Marion' and was greater in both cultivars with hand-weeding $\left(2.2 \mathrm{t} \cdot \mathrm{ha}^{-1}\right)$ or weed mat $\left(2.5 \mathrm{t} \cdot \mathrm{ha}^{-1}\right)$ than with no weeding $\left(1.3 \mathrm{t} \cdot \mathrm{ha}^{-1}\right)$ (data not shown; adapted from Harkins et al., 2013). As a result of differences in DW, 'Marion' primocanes contained a higher content of most nutrients than 'Black Diamond' after the second season, including all but $\mathrm{Ca}$ among the macronutrients and all but $\mathrm{Mn}$ and $\mathrm{Zn}$ among the micronutrients (Table 4). Primocanes also contained more nutrients with weed control than with no weeding but were similar regardless of the method of weed control. With hand-weeding or weed mat, 'Black Diamond' and 'Marion' accumulated an average of 22 and $31 \mathrm{~kg} \cdot \mathrm{ha}^{-1}$ of $\mathrm{N}$, 3 and $4 \mathrm{~kg} \cdot \mathrm{ha}^{-1}$ of $\mathrm{P}, 15$ and $19 \mathrm{~kg} \cdot \mathrm{ha}^{-1}$ of $\mathrm{K}$, 
Table 3. Fruit nutrient concentrations during the first year of production (Year 3) in two cultivars of organic trailing blackberry.

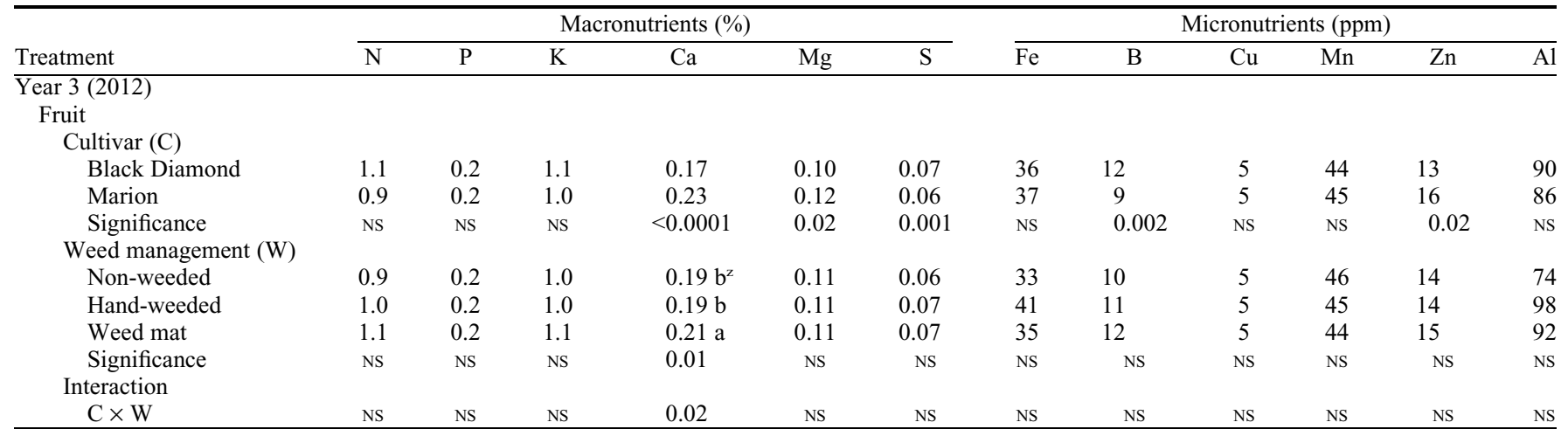

${ }^{\mathrm{z}}$ Means were separated at the 0.05 level using Fisher's protected least significant difference test. NS $=$ nonsignificant.
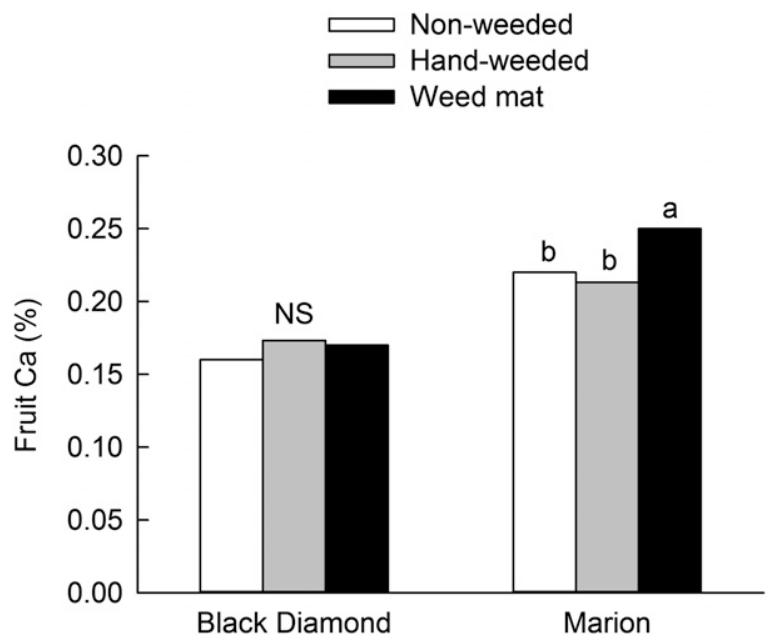

Fig. 4. Effects of three different weed management strategies on fruit calcium (Ca) concentration during the first year of fruit production (Year 3) in 'Black Diamond' and 'Marion' blackberry. Each bar represents the mean of three replicates. Means were separated within cultivars using Tukey's honestly significant difference test $(P=0.05)$. Ns Nonsignificant.

11 and $12 \mathrm{~kg} \cdot \mathrm{ha}^{-1}$ of $\mathrm{Ca}, 2$ and $3 \mathrm{~kg} \cdot \mathrm{ha}^{-1}$ of $\mathrm{Mg}, 1$ and $2 \mathrm{~kg} \cdot \mathrm{ha}^{-1}$ of S, 143 and $322 \mathrm{~g} \cdot \mathrm{ha}^{-1}$ of Fe, 30 and $45 \mathrm{~g} \cdot \mathrm{ha}^{-1}$ of B, 8 and $15 \mathrm{~g} \cdot \mathrm{ha}^{-1}$ of $\mathrm{Cu}, 285$ and $344 \mathrm{~g} \cdot \mathrm{ha}^{-1}$ of $\mathrm{Mn}, 61$ and 74 $\mathrm{g} \cdot \mathrm{ha}^{-1}$ of $\mathrm{Zn}$, and 125 and $310 \mathrm{~g} \cdot \mathrm{ha}^{-1}$ of $\mathrm{Al}$, respectively, in the primocanes during the second year after planting. No weed control, on the other hand, reduced uptake of each nutrient anywhere from $60 \%$ to $138 \%$ in 'Black Diamond' and from $61 \%$ to $232 \%$ in 'Marion' (data not shown).

Plants were first cropped during the third year after planting and therefore had both primocanes and floricanes present by harvest. The floricanes produced $1.2 \mathrm{t} \cdot \mathrm{ha}^{-1} \mathrm{DW}$ of fruiting laterals and $1.9 \mathrm{t} \cdot \mathrm{ha}^{-1} \mathrm{DW}$ of fruit (Fig. 1E), which was comparable to that produced by mature 'Kotata' blackberry plants grown conventionally (Mohadjer et al., 2001). Fruit DW was similar between cultivars but averaged $1.9 \mathrm{t} \cdot \mathrm{ha}^{-1}$ with handweeding, $2.3 \mathrm{t} \cdot \mathrm{ha}^{-1}$ with weed mat, and only $1.4 \mathrm{t} \cdot \mathrm{ha}^{-1}$ with no weeding (data not shown; adapted from Harkins et al., 2013). Consequently, total content of most nutrients in the fruit was also similar between cultivarsexcept $\mathrm{S}$ and $\mathrm{B}$, which were higher in 'Black
Diamond', and $\mathrm{Mg}$ and $\mathrm{Zn}$, which were higher in 'Marion'. Total fruit nutrient content was higher with weed control than without it and, in most cases (i.e., all except $\mathrm{Fe}, \mathrm{Cu}, \mathrm{Al}$ ), were higher with weed mat than with hand weeding (Table 5). The total amount of nutrients removed with the fruit in each treatment averaged 11 to $26 \mathrm{~kg} \cdot \mathrm{ha}^{-1}$ of $\mathrm{N}, 3$ to $5 \mathrm{~kg} \cdot \mathrm{ha}^{-1}$ of P, 12 to $27 \mathrm{~kg} \cdot \mathrm{ha}^{-1}$ of $\mathrm{K}, 2$ to $6 \mathrm{~kg} \cdot \mathrm{ha}^{-1}$ of Ca, 1 to $3 \mathrm{~kg} \cdot \mathrm{ha}^{-1}$ of $\mathrm{Mg}, 1$ to 2 $\mathrm{kg} \cdot \mathrm{ha}^{-1}$ of S, 44 to $82 \mathrm{~g} \cdot \mathrm{ha}^{-1}$ of Fe, 11 to 30 $\mathrm{g} \cdot \mathrm{ha}^{-1}$ of $\mathrm{B}, 6$ to $12 \mathrm{~g} \cdot \mathrm{ha}^{-1}$ of $\mathrm{Cu}, 56$ to 110 $\mathrm{g} \cdot \mathrm{ha}^{-1}$ of Mn, 18 to $40 \mathrm{~g} \cdot \mathrm{ha}^{-1}$ of $\mathrm{Zn}$, and 93 to $240 \mathrm{~g} \cdot \mathrm{ha}^{-1}$ of $\mathrm{Al}$.

Nutrients were also removed with pruning of senescing floricanes after harvest, which likewise differed with cultivar in many cases and was always affected by weed management (Table 5). 'Marion' had more N, Ca, $\mathrm{Mg}, \mathrm{S}, \mathrm{Fe}, \mathrm{B}$, and $\mathrm{Al}$ in the floricanes at pruning than 'Black Diamond', although significant interactions between cultivar and weed management indicated that $\mathrm{N}$ and $\mathrm{Mg}$ were only higher in 'Marion' when plants were grown with weed control (Fig. 5). Both methods of weed control increased nutrient content in the floricanes, but some nutrients, including $\mathrm{N}, \mathrm{P}, \mathrm{K}, \mathrm{Ca}, \mathrm{S}$, and $\mathrm{Cu}$, were also higher with weed mat than with handweeding. Total removal of nutrients in the floricanes was often at least twice that of the fruit-and sometimes much higher (e.g., Ca, $\mathrm{Mg}, \mathrm{Fe}, \mathrm{B}, \mathrm{Mn}, \mathrm{Zn}$, and $\mathrm{Al}$ ) - and depending on the treatment averaged 22 to $55 \mathrm{~kg} \cdot \mathrm{ha}^{-1}$ of $\mathrm{N}, 2$ to $7 \mathrm{~kg} \cdot \mathrm{ha}^{-1}$ of $\mathrm{P}, 23$ to $58 \mathrm{~kg} \cdot \mathrm{ha}^{-1}$ of $\mathrm{K}$, 20 to $54 \mathrm{~kg} \cdot \mathrm{ha}^{-1}$ of Ca, 3 to $12 \mathrm{~kg} \cdot \mathrm{ha}^{-1}$ of $\mathrm{Mg}$, 1 to $4 \mathrm{~kg} \cdot \mathrm{ha}^{-1}$ of S, 330 to $730 \mathrm{~g} \cdot \mathrm{ha}^{-1}$ of Fe, 56 to $280 \mathrm{~g} \cdot \mathrm{ha}^{-1}$ of B, 8 to $23 \mathrm{~g} \cdot \mathrm{ha}^{-1}$ of $\mathrm{Cu}, 550$ to $1240 \mathrm{~g} \cdot \mathrm{ha}^{-1}$ of Mn, 89 to $200 \mathrm{~g} \cdot \mathrm{ha}^{-1}$ of $\mathrm{Zn}$, and 310 to $760 \mathrm{~g} \cdot \mathrm{ha}^{-1}$ of $\mathrm{Al}$.

The total amount of $\mathrm{N}$ removed in the floricanes and fruit exceeded the amount applied as fertilizer in the third year in most treatments. For example, $65 \mathrm{~kg} \cdot \mathrm{ha}^{-1}$ of $\mathrm{N}$ was removed from 'Black Diamond' plots with weed mat and $75 \mathrm{~kg} \cdot \mathrm{ha}^{-1}$ of $\mathrm{N}$ was removed from 'Marion' plots with weed mat, but only $53 \mathrm{~kg} \cdot \mathrm{ha}^{-1}$ of $\mathrm{N}$ was applied the third year (Table 1). Likewise, 35 to $85 \mathrm{~kg} \cdot \mathrm{ha}^{-1}$ of $\mathrm{K}$ was removed in each treatment, which for some treatments was more than the $62 \mathrm{~kg} \cdot \mathrm{ha}^{-1}$ of $\mathrm{K}$ applied in the third year (Table 1). Over time, $\mathrm{N}$ and $\mathrm{K}$ would diminish in these plots unless more organic fertilizer was applied. However, the available nutrients in the soil may be sufficient. In addition, most commercial growers flail (chop) the prunings in the row middles, and thus any nutrients in the spent floricanes are returned to the soil and potentially available to the plants the next years (Ledgard et al., 1992; Rempel et al., 2004). Using ${ }^{15} \mathrm{~N}$ as a tracer, Strik et al. (2006) calculated that up to $8 \%$ of the $\mathrm{N}$ in raspberry floricane prunings was available for plant uptake with 1.5 years. In our case, $66 \%$ to $74 \%$ of the $\mathrm{N}$ and $47 \%$ to $93 \%$ of other nutrients considered removed or "lost" would be returned to the field by flailing the prunings and potentially be available to the blackberry plants.

New primocane growth was limited during the third season and based on primocane number was estimated to average only 0.2 t.ha ${ }^{-1}$ DW in each treatment, which was only $10 \%$ of total primocane DW produced the previous year (Fig. 1F). The estimated nutrient gain was thus likewise low and, based on primocane nutrient concentrations from the previous year, averaged 2 to $3 \mathrm{~kg} \cdot \mathrm{ha}^{-1}$ of $\mathrm{N} ; 1$ 


\begin{tabular}{|c|c|c|c|c|c|c|c|c|c|c|c|c|}
\hline \multirow[b]{2}{*}{ Treatment } & \multicolumn{6}{|c|}{ Macronutrients $\left(\mathrm{kg} \cdot \mathrm{ha}^{-1}\right)$} & \multicolumn{6}{|c|}{ Micronutrients $\left(\mathrm{g} \cdot \mathrm{ha}^{-1}\right)$} \\
\hline & $\mathrm{N}$ & $\mathrm{P}$ & $\mathrm{K}$ & $\mathrm{Ca}$ & $\mathrm{Mg}$ & $\mathrm{S}$ & $\mathrm{Fe}$ & B & $\mathrm{Cu}$ & $\mathrm{Mn}$ & $\mathrm{Zn}$ & $\mathrm{Al}$ \\
\hline \multicolumn{13}{|l|}{ Primocanes (removed) } \\
\hline \multicolumn{13}{|l|}{ Cultivar (C) } \\
\hline Marion & 5.4 & 0.6 & 1.9 & 1.3 & 0.5 & 0.2 & 142 & 7 & 3 & 87 & 19 & 133 \\
\hline Significance & NS & NS & NS & $<0.0001$ & NS & NS & NS & NS & NS & $<0.0001$ & 0.01 & 0.04 \\
\hline \multicolumn{13}{|c|}{ Weed management $(\mathrm{W})$} \\
\hline Significance & NS & NS & NS & NS & NS & NS & 0.0001 & NS & 0.01 & NS & NS & $<0.0001$ \\
\hline \multicolumn{13}{|l|}{ Interaction } \\
\hline $\mathrm{C} \times \mathrm{W}$ & NS & NS & NS & NS & NS & NS & NS & NS & NS & NS & NS & NS \\
\hline \multicolumn{13}{|l|}{ Year 2 (2011) } \\
\hline \multicolumn{13}{|l|}{ Primocanes } \\
\hline \multicolumn{13}{|l|}{ Cultivar (C) } \\
\hline Hand-weeded & $24.7 \mathrm{a}$ & $3.1 \mathrm{a}$ & $15.8 \mathrm{a}$ & $11.3 \mathrm{a}$ & $2.7 \mathrm{a}$ & $1.3 \mathrm{a}$ & $268 \mathrm{a}$ & $36 \mathrm{a}$ & $11 \mathrm{a}$ & $313 \mathrm{a}$ & $64 \mathrm{a}$ & $261 \mathrm{a}$ \\
\hline Weed mat & $29.2 \mathrm{a}$ & $3.7 \mathrm{a}$ & $18.2 \mathrm{a}$ & $11.5 \mathrm{a}$ & $2.9 \mathrm{a}$ & $1.5 \mathrm{a}$ & $197 \mathrm{a}$ & $38 \mathrm{a}$ & $13 \mathrm{a}$ & $316 \mathrm{a}$ & $70 \mathrm{a}$ & $174 \mathrm{ab}$ \\
\hline Significance & $<0.0001$ & $<0.0001$ & $<0.0001$ & $<0.0001$ & $<0.0001$ & $<0.0001$ & 0.003 & $<0.0001$ & $<0.0001$ & 0.003 & 0.002 & 0.01 \\
\hline \multicolumn{13}{|l|}{ Interaction } \\
\hline $\mathrm{C} \times \mathrm{W}$ & NS & NS & NS & NS & NS & NS & NS & NS & NS & NS & NS & NS \\
\hline
\end{tabular}

${ }^{\mathrm{z}}$ Weeds were controlled by hand-weeding or weed mat each year or by hand-weeding the first year (2010) but no weeding the next years.

'Because the non-weeded treatment was hand-weeded during the first year after planting, means of the hand-weeded treatment include the average of handweeded and non-weeded plots in 2010 .

${ }^{x}$ Means were separated at the 0.05 level using Fisher's protected least significant difference test.

NS $=$ nonsignificant.

Black Diamond

ए]m Marion
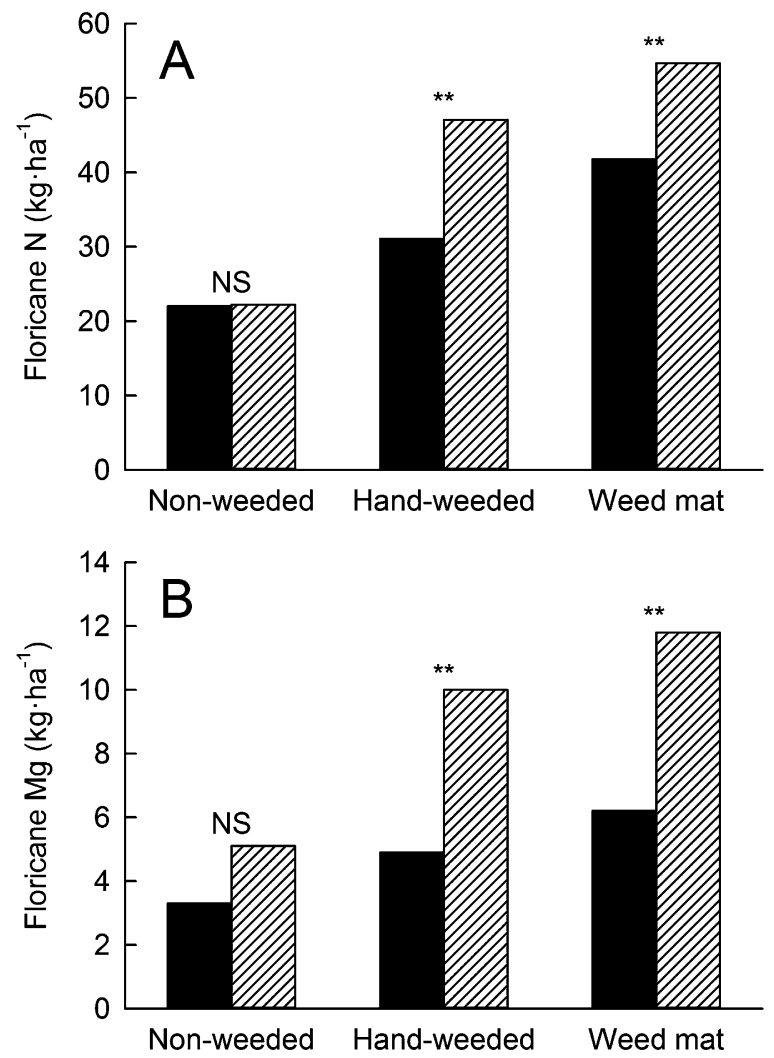

Fig. 5. Effects of three different weed management strategies on $(\mathbf{A})$ nitrogen $(\mathrm{N})$ and $\mathbf{B})$ magnesium $(\mathrm{Mg})$ content in senescing floricanes after harvest during the first year of fruit production (Year 3) in 'Black Diamond' and 'Marion' blackberry. Each bar represents the mean of three replicates. Cultivars were compared within each weed management strategy using the $t$ test. Ns, **Nonsignificant or significant at $P \leq 0.01$, respectively. to $2 \mathrm{~kg} \cdot \mathrm{ha}^{-1}$ of Ca and $\mathrm{K}$; less than $1 \mathrm{~kg} \cdot \mathrm{ha}^{-1}$ of $\mathrm{P}, \mathrm{Mg}$, and $\mathrm{S} ; 16$ to $34 \mathrm{~g} \cdot \mathrm{ha}^{-1}$ of $\mathrm{Fe} ; 3$ to 5 $\mathrm{g} \cdot \mathrm{ha} \mathrm{C}^{-1}$ of $\mathrm{B} ; 1$ to $2 \mathrm{~g} \cdot \mathrm{ha}^{-1}$ of $\mathrm{Cu} ; 29$ to $40 \mathrm{~g} \cdot \mathrm{ha}^{-1}$ of $\mathrm{Mn}$; 6 to $9 \mathrm{~g} \cdot \mathrm{ha}^{-1}$ of $\mathrm{Zn}$; and 14 to $34 \mathrm{~g} \cdot \mathrm{ha}^{-1}$ of Al. Mohadjer et al. (2001) compared primocane growth in 'Kotata' blackberry grown in an alternate-year production system and similarly found that primocane growth during an "on year," when floricanes and primocanes were present, was only $\approx 30 \%$ of what was produced during an "off year," when plants had only primocanes. Floricanes compete with the primocanes for resources in caneberry plants and therefore may reduce not only primocane growth but nutrient uptake by the primocanes as well (Bryla and Strik, 2008; Cortell and Strik, 1997; Malik et al., 1991; Mohadjer et al., 2001; Naraguma et al., 1999; Rempel et al., 2004; Wright and Waister, 1982).

Net biomass or nutrient gains may have been grossly underestimated in the present study because the plants were not measured below ground. Blackberry roots account for $26 \%$ to $41 \%$ of the total plant biomass and serve as an important reserve of nutrients (Malik et al., 1991; Naraguma et al., 1999). Blackberry and red raspberry use up to $40 \%$ of the $\mathrm{N}$ stored in the crown and roots for new shoot growth (Mohadjer et al., 2001; Rempel et al., 2004). Nutrients lost during leaf senescence were also not estimated, although when trailing blackberry is grown in a mild climate such as Oregon's Willamette Valley, where the majority of the crop is produced, not all primocane leaves senesce before the plants resuming growth the next spring. 
Table 5. Total nutrient content in the fruit and senescing floricanes during the first year of production (Year 3) in two cultivars of organic trailing blackberry. ${ }^{z}$

\begin{tabular}{|c|c|c|c|c|c|c|c|c|c|c|c|c|}
\hline \multirow[b]{2}{*}{ Treatment } & \multicolumn{6}{|c|}{ Macronutrients $\left(\mathrm{kg} \cdot \mathrm{ha}^{-1}\right)$} & \multicolumn{6}{|c|}{ Micronutrients $\left(\mathrm{g} \cdot \mathrm{ha}^{-1}\right)$} \\
\hline & $\mathrm{N}$ & $\mathrm{P}$ & $\mathrm{K}$ & $\mathrm{Ca}$ & $\mathrm{Mg}$ & $\mathrm{S}$ & $\mathrm{Fe}$ & B & $\mathrm{Cu}$ & $\mathrm{Mn}$ & $\mathrm{Zn}$ & $\mathrm{Al}$ \\
\hline \multirow{2}{*}{\multicolumn{13}{|c|}{$\begin{array}{l}\text { Ripe fruit (harvested) } \\
\text { Cultivar }(\mathrm{C})\end{array}$}} \\
\hline & & & & & & & & & & & & \\
\hline Marion & 17.1 & 3.7 & 18.0 & 2.2 & 4.3 & 1.2 & 70 & 18 & 10 & 87 & 29 & 159 \\
\hline Significance & NS & NS & NS & NS & 0.0002 & 0.04 & NS & 0.005 & NS & NS & 0.04 & NS \\
\hline \multicolumn{13}{|c|}{ Weed management $(\mathrm{W})$} \\
\hline Weed mat & $25.2 \mathrm{a}$ & $4.7 \mathrm{a}$ & $25.2 \mathrm{a}$ & $5.0 \mathrm{a}$ & $2.7 \mathrm{a}$ & $1.7 \mathrm{a}$ & $82 \mathrm{a}$ & $27 \mathrm{a}$ & $12 \mathrm{a}$ & $102 \mathrm{a}$ & $36 \mathrm{a}$ & $212 \mathrm{a}$ \\
\hline Significance & 0.0003 & 0.0003 & 0.0002 & $<0.0001$ & 0.0003 & 0.001 & 0.003 & 0.0002 & 0.01 & 0.002 & 0.0001 & 0.03 \\
\hline \multicolumn{13}{|l|}{ Interaction } \\
\hline $\mathrm{C} \times \mathrm{W}$ & NS & NS & NS & NS & NS & NS & NS & NS & NS & NS & NS & NS \\
\hline \multicolumn{13}{|c|}{ Senescing floricanes (pruned) } \\
\hline \multicolumn{13}{|c|}{ Cultivar (C) } \\
\hline Hand-weeded & $38.7 \mathrm{~b}$ & $5.6 \mathrm{~b}$ & $45.1 \mathrm{~b}$ & $36.7 \mathrm{~b}$ & $7.4 \mathrm{a}$ & $2.6 \mathrm{~b}$ & $636 \mathrm{a}$ & $156 \mathrm{a}$ & $16 \mathrm{~b}$ & $928 \mathrm{a}$ & $206 \mathrm{a}$ & $618 \mathrm{a}$ \\
\hline Weed mat & $47.8 \mathrm{a}$ & $7.2 \mathrm{a}$ & $56.7 \mathrm{a}$ & $45.5 \mathrm{a}$ & $8.9 \mathrm{a}$ & $3.2 \mathrm{a}$ & $680 \mathrm{a}$ & $190 \mathrm{a}$ & $20 \mathrm{a}$ & $1078 \mathrm{a}$ & $182 \mathrm{a}$ & $688 \mathrm{a}$ \\
\hline Significance & $<0.0001$ & $<0.0001$ & $<0.0001$ & $<0.0001$ & $<0.0001$ & $<0.0001$ & 0.001 & $<0.0001$ & 0.001 & 0.01 & 0.02 & 0.001 \\
\hline \multicolumn{13}{|l|}{ Interaction } \\
\hline $\mathrm{C} \times \mathrm{W}$ & 0.04 & NS & NS & NS & 0.04 & NS & NS & NS & NS & NS & NS & NS \\
\hline
\end{tabular}

${ }^{2}$ Weeds were controlled by hand-weeding or weed mat each year or by hand-weeding the first year (2010) but no weeding the next years.

${ }^{y}$ Means were separated at the 0.05 level using Fisher's protected least significant difference test.

NS $=$ nonsignificant.

\section{Conclusions}

Based on the current standards for primocane leaf tissue analysis in caneberries, the organic fertilizers used in the present study were adequate to meet plant demands for $\mathrm{P}$ and $\mathrm{K}$ in blackberry but were inadequate to meet the need for $\mathrm{N}$ in 'Black Diamond' and $\mathrm{B}$ in 'Black Diamond' and 'Marion'. 'Black Diamond' may have a need for more fertilizer than the $53 \mathrm{~kg} \cdot \mathrm{ha}^{-1} \mathrm{~N}$ applied per year but alternately may have lower leaf tissue nutrient requirements. The results also indicate that more fertilizer may also be needed with limited or no weed control, although additional application may likewise increase weed growth. Low B is easily resolved with a broadcast application of boric acid in the fall or before budbreak in the spring. Hart et al. (2006) recommended applying no more than $3 \mathrm{~kg} \cdot \mathrm{ha}^{-1}$ of $\mathrm{B}$ in any given year and to avoid further application once primocane leaf B levels are adequate (greater than $30 \mathrm{ppm}$ ).

In terms of gains in biomass, aboveground plant growth was greater in 'Marion' than in 'Black Diamond' during the second year after planting when only primocanes were present but was similar between cultivars the next year when plants were first cropped. Weed control, however, increased cane and fruit biomass, leaf tissue nutrient concentrations, and nutrient accumulation and loss in both cultivars. Nutrient gains exceeded nutrients applied in the organic fertilizer during the first year of fruit production (with weed control) and therefore relied on plant tissue reserves and/or soil nutrients to meet plant demands.

\section{Literature Cited}

Bryla, D.R. and B.C. Strik. 2008. Do primocanes and floricanes compete for soil water in blackberry? Acta Hort. 777:477-482.

Cortell, J.M. and B.C. Strik. 1997. Effect of floricane number in 'Marion' trailing blackberry. II. Yield components and dry mass partitioning. J. Amer. Soc. Hort. Sci. 122:611-615.

Gavlak, R.G., D.A. Horneck, and R.O. Miller. 1994. Soil and plant tissue reference methods for the western region. Univ. Alaska Western Reg. Publ. 125.

Hanger, B.C. 1979. Movement of calcium in plants. Commun. Soil Sci. Plant Anal. 10:171193.

Harkins, R.H. 2013. Weed, water, and nutrient management practices for organic blackberry production. MS thesis, Ore. St. Univ., Corvallis, OR. 15 July 2013. <http://ir.library.oregonstate. edu/xmlui/bitstream/handle/1957/40102/Harkins ReneeH2013.pdf? sequence $=1>$.

Harkins, R.H., B.C. Strik, and D.R. Bryla. 2013. Weed management practices for organic production of trailing blackberry. I. Plant growth and early fruit production. HortScience 48: 1139-1144.

Hart, J., B. Strik, and H. Rempel. 2006. Caneberries. Nutrient management guide. Ore. State Univ. Ext. Serv., EM 8903-E.

Ho, L.C. and P.J. White. 2005. A cellular hypothesis for the induction of blossom-end rot in tomato fruit. Ann. Bot. (Lond.) 95:571-581.

Julian, J.W., C.F. Seavert, B.C. Strik, and D. Kaufman. 2009. Berry economics: Establishing and producing Marion blackberries in the Willamette Valley. Ore. St. Univ. Ext. Serv., EM 8773.

Julian, J.W., B.C. Strik, H.O. Larco, D.R. Bryla, and D.M. Sullivan. 2012. Costs of establishing organic northern highbush blueberry: Impacts of planting method, fertilization, and mulch type. HortScience 47:866-873.
Kafkafi, U. and J. Tarchitzky. 2011. Fertigation: A tool for efficient fertilizer and water management. Intl. Fert. Ind. Assn., Paris, France.

Larco, H., B.C. Strik, D.R. Bryla, and D.M. Sullivan. 2013. Mulch and fertilizer management practices for organic production of highbush blueberries. II. Impact on plant and soil nutrients during establishment. HortScience 48:1484-1495.

Ledgard, S.F., G.S. Smith, and M.S. Sprosen. 1992 Fate of ${ }^{15} \mathrm{~N}$-labelled nitrogen fertilizer applied to kiwifruit (Actinidia deliciosa) vines. I. ${ }^{15} \mathrm{~N}$ recovery in plant and soil. Plant Soil 147:4957.

Makus, D.J. 2011. Use of synthetic ground covers to control weeds in blackberries. Intl. J. Fruit Sci. 11:286-298.

Malik, H., D.D. Archbold, and C.T. MacKown. 1991. Nitrogen partitioning by 'Chester Thornless' blackberry in pot culture. HortScience 26:1492-1494.

Mattson, N.S. and M.W. van Iersel. 2011. Application of the '4R' nutrient stewardship concept to horticultural crops: Applying nutrients at the right time. HortTechnology 21:667-673.

McLaughlin, S.B. and R. Wimmer. 1999. Calcium deficiency and terrestrial ecosystem processes. New Phytol. 142:373-417.

McLean, E.O. 1982. Soil pH and lime requirement, p. 199-223. In: Page, A.L., R.H. Miller, and D.R. Keeney (eds.). Methods of soil analysis. Part 2. Chemical and microbiological properties. 2nd Ed. Agron. Monogr. 9. Soil Sci. Soc. Amer., Madison, WI.

Mohadjer, P., B.C. Strik, B.J. Zebarth, and T.L. Righetti. 2001. Nitrogen uptake, partitioning and remobilization in 'Kotata' blackberry in alternate-year production. J. Hort. Sci. Biotechnol. 76:700-708.

Montanaro, G., B. Dichio, and C. Xiloyannis. 2010. Significance of fruit transpiration on calcium nutrition in developing apricot fruit. J. Plant Nutr. Soil Sci. 173:618-622. 
Montanaro, G., B. Dichio, C. Xiloyannis, and G. Celano. 2006. Light influences transpiration and calcium accumulation in fruit of kiwifruit plants (Actinidia deliciosa var. deliciosa). Plant Sci. 170:520-527.

Naraguma, J., J.R. Clark, R.J. Norman, and R.W. McNew. 1999. Nitrogen uptake and allocation by field-grown 'Arapaho' thornless blackberry. J. Plant Nutr. 22:753-768.

National Agricultural Statistical Service. 2010. 2007 Census of agriculture-Organic production survey (2008). Vol. 3, special studies, part 2. U.S. Dept. Agric., Natl. Agr. Stat. Serv., Washington, DC.

Percival, D.C., J.T.A. Proctor, and J.A. Sullivan. 1998. Supplementary irrigation and mulch benefit the establishment of 'Heritage' primocanefruiting raspberry. J. Amer. Soc. Hort. Sci. 123:518-523.

Rempel, H.G., B.C. Strik, and T.L. Righetti. 2004. Uptake, partitioning, and storage of fertilizer nitrogen in red raspberry as affected by rate and timing of application. J. Amer. Soc. Hort. Sci. 129:439-448

Strik, B., T. Righetti, and H. Rempel. 2006. Black plastic mulch improved the uptake of ${ }^{15}$ nitrogen from inorganic fertilizer and organic prunings in summer-bearing red raspberry. HortScience 41 $272-274$.

Strik, B.C., J.R. Clark, C.E. Finn, and M.P. Bañados. 2007. Worldwide blackberry production. HortTechnology 17:205-213.
Strik, B.C. and C.E. Finn. 2012. Blackberry production systems - A worldwide perspective. Acta Hort. 946:341-347.

USDA Plant Hardiness Zone Map. 2012. Agricultural Research Service, U.S. Department of Agriculture. <http://planthardiness.ars. usda.gov>.

Willard, D. and H.H. Valenti. 2008. Juneberry growth is affected by weed control methods. HortTechnology 18:75-79.

Wright, C.J. and P.D. Waister. 1982. With-in plant competition in the red raspberry. I. Primocane growth. J. Hort. Sci. 57:437-444.

Zibilske, L.M. 2010. Permeability of fabric ground covers to organically-derived nutrients. Intl. J. Fruit Sci. 10:109-122. 